\title{
[gw22-e0339] EFFECTS OF ANGIOTENSIN II AND TELMISARTAN ON TRANSIENT OUTWARD POTASSIUM AND L-TYPE CALCIUM CURRENTS IN SPRAGUE- DAWLEY RAT ATRIAL MYOCYTES
}

Long Yi, Zhou Yanan, Fan JinqiThe Second Affiliated Hospital Of Chongqing Medical University, Chongqing, China

10.1136/heartjnl-2011-300867.173

Objective To explore possible electrophysiological mechanisms of single atrial myocyte by evaluating the effects of angiotensinII (AngII) and telmisartan on transient outward potassium currents $\left(\mathrm{I}_{\text {to }}\right)$ and L-type calcium currents $\left(\mathrm{I}_{\mathrm{Ca}-\mathrm{L}}\right)$ in Sprague-Dawley rats.

Methods Single atrial myocyte of SD rats was obtained by enzymatic dissociation method. The whole cell patch-clamp recording technique was used to record the change of $I_{\text {to }}$ and $\mathrm{I}_{\mathrm{Ca}-\mathrm{L}}$ by intervening of AngII, telmisartan and AngII plus telmisartan, respectively. Experimental groups: (1) AngII group: cells were perfused with bath solution containing AngII ( 0.1 $\mu \mathrm{mol} / \mathrm{l})$; (2) Telmisartan group: cells were perfused with bath solution containing telmisartan $(0.01 \mu \mathrm{mol} / \mathrm{l})$; (3) Combined group, myocytes were perfused with bath solution containing AngII (0.1 $\mu \mathrm{mol} / \mathrm{l})$ and telmisartan $(0.01 \mu \mathrm{mol} / \mathrm{l})$.

Results Compared with baseline value, AngII (0.1 $\mathrm{mol} / \mathrm{l})$, Telmisartan (0.01 $\mu \mathrm{mol} / \mathrm{l})$ and AngII plus Telmisartan group significantly decreased the peak density of $\mathrm{I}_{\text {to }}$ in $\mathrm{SD}$ rat atrial myocytes $(22.48 \pm 2.75$ vs $15.71 \pm 2.06 \mathrm{pA} / \mathrm{pF}, \mathrm{p}<0.01)$, $(24.16 \pm 2.36$ vs $16.15 \pm 1.82 \mathrm{pA} / \mathrm{pF}, \mathrm{p}<0.01)$ and $(24.41 \pm 2.27 \mathrm{vs}$ $21.35 \pm 1.46 \mathrm{pA} / \mathrm{pF}, \mathrm{p}<0.05)$, respectively. AngII $(0.1 \mu \mathrm{mol} / \mathrm{l})$ significantly increased the peak density of $\mathrm{I}_{\mathrm{Ca}-\mathrm{L}}$ in $\mathrm{SD}$ rat atrial myocytes $(-4.51 \pm 0.38$ vs $-5.16 \pm 0.29 \mathrm{pA} / \mathrm{pF}, \mathrm{p}<0.01)$. Telmisartan $(0.01 \mu \mathrm{mol} / \mathrm{l})$ had no significant effect on $\mathrm{I}_{\mathrm{Ca}-\mathrm{L}}$ in the rat atrial myocytes $(-4.35 \pm 0.27 \mathrm{vs}-4.29 \pm 0.34 \mathrm{pA} / \mathrm{pF}$, $\mathrm{p}>0.05$ ), but it could antagonise the effects of AngII. In the Ang IIcombined telmisartan group, the peak density of $\mathrm{I}_{\mathrm{Ca}-\mathrm{L}}$ was $(-4.08 \pm 0.28$ vs $-4.20 \pm 0.31 \mathrm{pA} / \mathrm{pF}, \mathrm{p}>0.05)$, which was significantly different from that of AngII group $(p<0.05)$.

Conclusion AngII and telmisartan had directly electrophysiological effects on SD rat atrial myocytes as well as telmisartan had antagonist effects on AngII at the level of angiotensin receptor. 